\title{
THE PROBLEM OF FUGITIVE FELONS AND WITNESSES
}

\author{
Harry S. Toy* and Edmund E. Shepherd $\dagger$
}

On January Ir, I934, the Honorable Royal S. Copeland, United States Senator from the State of New York, as chairman of the subcommittee of the Committee on Commerce, popularly known as the "Committee on "Racketeering," and subsequently designated the "Committee on Crime and Criminal Practices," of which Senators Vandenberg of Michigan and Murphy of Iowa are also active members, introduced for the committee some thirteen bills, all of which were designed to close gaps in existing federal laws, and to render more difficult the activities of predatory criminal gangs of the Kelly and Dillinger types. Of these bills, eleven have become law, and some 30 others, of like origin and purpose, remain to be considered by the Congress at its coming session. ${ }^{1}$

Among the bills adopted by the 73rd Congress, with which this article will deal, is Public Act No. 233, approved by the President May 18, 1934, entitled, "An Act making it unlawful for any person to flee from one state to another for the purpose of avoiding prosecution or the giving of testimony in certain cases." This legislative measure, containing one section, provides:

Be it enacted, etc., That it shall be unlawful for any person to move or travel in interstate commerce from any state, territory or possession of the United States, or the District of Columbia, with intent either ( $\mathrm{r}$ ) to avoid prosecution for murder, kidnaping, burglary, robbery, mayhem, rape, assault with a dangerous weapon, or extortion accompanied by threats of violence, or attempt to commit any of the foregoing, under the laws of the place from which he flees, or (2) to avoid giving testimony in any criminal proceedings in which a felony is charged. Any person who violates the provisions of this act shall, upon conviction thereof, be punished by a fine of not more than $\$ 5,000$ or by imprisonment for not longer than 5 years, or by both such fine and imprisonment. Violations of this act may be prosecuted only in the Federal judicial district in which the original crime was alleged to have been committed.

- LI.B., I913, Detroit College of Law. Assistant Prosecuting Attorney, Wayne County (Detroit), I9201922; Prosecuting Attorney, I930-1934. At present Republican candidate for office of Attorney General, Michigan.

t LL.B., 1906, Detroit College of Law. Assistant Prosecuting Attorney, Wayne County (Detroit) since 1931. In charge of all criminal causes pending on appeal to Michigan State Supreme Court.

${ }^{I}$ Report of Senator Copeland, June I4, I934, as Chairman of Subcommittee of the Committee on Commerce on S. Res. 74 (cont. by S. Res. 196), 73rd Cong., 2nd Sess. 78 CoNG. Rec. II799 (1934). 
In the June number of the Detroit Law Review, under the title, "Congressional Power to Restrain Interstate Flight of Witnesses," we had occasion to consider the constitutionality of this act, and we there maintained that the Congress had validly exercised its powers under the interstate commerce clause of the Federal Constitution. $^{3}$ While, in this current article, we may possibly repeat certain observations noted in our former discussion, the subject is approached from quite a different angle.

In formulating the first ten Amendments to the Federal Constitution, and in preparing the state constitutions which followed, the authors of these several instruments were extremely zealous in conserving for the individual citizen those personal liberties, privileges, and immunities which, in the course of English and American history, under development of the common law, had gradually been wrested from the autocracy of both King and Parliament. Since these inhibitions were designed primarily to afford a shield from governmental tyranny and oppression, no person living in that period was so prophetically endowed as to entertain the preposterous idea that, in later years and under radically changed conditions, these guaranties of personal liberty might be turned as a sword upon organized society by a predatory class of criminals operating on the nationwide scale prevalent at the present time. Nevertheless, it is manifest to the mere casual observer that, in our generation, one of the most difficult tasks confronting legislative bodies, law-enforcing agencies, and the courts themselves, is to devise some valid means of social protection from vicious results of a flagrant distortion of these very safeguards. And it seems impossible to evade the question: how much longer shall we permit mere sentimentality for an ancient and honored theory of personal liberty to jeopardize the lives and safety of the majority of our citizens; and in what degree, under changed conditions, should individual rights of personal liberty of action, in the main invoked only by the felon, yield for the good of the whole, for the safety of society, and how may this be accomplished without relinquishing entirely such constitutional safeguards? In short, what individual price must be paid for social safety?

Without digressing too far from the main theme, and solely by way of illustration: The Constitution of the United States, and the fundamental laws adopted by the majority of states, provide that the persons, houses, papers, and possessions of every person shall be secure from unreasonable searches and seizures. ${ }^{4}$ These several constitutional provisions accomplish their purpose, and expend their full force in guaranteeing the immunity, are not self-executing, carry no penalties, and prescribe no rule of evidence. Yet the Supreme Court of the United States, in what Professor John Henry Wigmore of Northwestern University terms an "ill-starred opinion,"

\footnotetext{
${ }_{2} 4$ Detrort L. Rev. (I934) no. 3 .

${ }^{3}$ U. S. Const. art. I, §8, cl. 3 .

$U$ U. S. Const. AMend. IV; Mich. Const. art ir, §io.

${ }_{4}$ WIgmore, Evidence (2nd ed. 1923) $\$ 2184$, p. 632 . The decision referred to is Boyd v. United States, I16 U. S. 616, 6 Sup. Ct. 524 (1886), followed in Weeks v. United States, 232 U. S. 383,34 Sup. Ct. 34 I (1914).
} 
followed by approximately eighteen courts of last resort throughout the nation, ${ }^{6}$ the latter doubtless at least in some degree influenced by official abuses which arose during the World War and as the result of adoption of the I8th Amendment, created by judicial fiat a rule of evidence which bars from courts of law any property seized as the result of an unreasonable search, and permits the criminal to go free though his guilt be well established. Thus it follows that the felon may safely stalk the highways of these states while armed with a lethal weapon concealed upon his person with murderous design, and, under the protection of this rule of evidence, openly and brazenly defy the police to do anything about it. Under this law, his sacred person is inviolate, even though it might be said that in arming himself thus feloniously he has waived his constitutional privileges. The eyes of Justice must be closed as the knife is thrust in her back. Whether repeal of prohibition measures will bring about a judicial abrogation of this rule, or whether the situation will be corrected by constitutional amendment, remains to be seen. All of which is in passing.

Frankly, then, one of the purposes of the Congressional Act now under discussion is to prevent the criminal from deliberately using one or two of these constitutional provisions as a sword against society. It is also designed to aid and assist state governmental agencies in the enforcement of local laws, to simplify rendition-or extradition, as it is commonly called-between the states, and to provide means of interstate rendition of fugitive witnesses.

Turning attention, first, to the subject of extradition of accused persons.

While it may be said that, prior to adoption of the Federal Constitution, the extradition of criminals depended largely upon international comity, we find by Winthrop's History of New England, ${ }^{7}$ as later pointed out by the United States Supreme Court, ${ }^{8}$ that as early as 1643 , by "articles of confederation between the plantations under the government of Massachusetts, the plantations under the government of New Plymouth, the plantations under the government of Connecticut, and the government of New Haven, with the plantations in combination therewith," these plantations pledged themselves to each other, that, upon the escape of any prisoner or fugitive for any criminal cause, whether by breaking prison, or getting from the officer, or otherwise escaping, upon the certificate of two magistrates of the jurisdiction out of which the escape was made, that he was a prisoner or such an offender at the time of the escape, the magistrate, or some of them, of "the jurisdiction where, for the present, the said prisoner fugitive abideth, shall forthwith grant such a warrant as the case will bear, for the apprehending of any such person, and the delivery of him into the hands of the officer or other person who pursueth him; and if there be help required for the safe returning of any such offender, then it shall be granted unto him that craves the same, he paying the charges thereof." It will be seen that

\footnotetext{
${ }^{8}$ See Note (1934) 88 A. L. R. 348: The following states have adopted the rulc denying admissibility: Florida, Idaho, Illinois, Indiana, Kentucky, Michigan, Mississippi, Missouri, Montana, Oklahoma, Oregon, South Dakota, Texas, Washington, West Virginia, Wisconsin, Wyoming.

${ }^{2} 2$ Winthrop, History of NEw England, 1630-1649 (Hosmer ed. 1908) 100, 104-5.

${ }^{8}$ Ex parte Kentucky v. Dennison, 24 How. 66 (U. S. 186r).
} 
this agreement gave no discretion to the magistrate of the government where the offender was found; but he was bound to arrest and deliver, upon the production of the certificate under which the offender was demanded.

It is also to be noted that prior to this intercolonial agreement, indeed, so far as we can ascertain, throughout European and American history, the right of an asylum state or country to arrest and surrender a fugitive fleeing from the justice of another nation or state has received uniform recognition. Thus, as pointed out by the Supreme Court of New Jersey, ${ }^{9}$ the English Court of King's Bench, during a very early period, and in Rex v. Hutchinson, ${ }^{10}$ upon habeas corpus, refused to bail a prisoner who was committed on suspicion of murder committed in Portugal. And in the case of Lundy, ${ }^{11}$ it was agreed, on a consultation of all the judges, that there was nothing in the habeas corpus act to prevent a person guilty of a capital offense in Ireland (then a distinct kingdom) being sent there to be tried.

When the thirteen colonies, having attained the status of separate and independent sovereignty, joined in the Articles of Confederation for mutual support, they entered into a compact respecting fugitives from justice, in the following words:

If any Person be guilty of, or charged with, treason, felony, or other high misdemeanor in any state, shall flee from Justice, and be found in any of the united states, he shall upon demand of the governor or executive power, of the state from which he fled, be delivered up and removed to the state having jurisdiction of his offense. ${ }^{12}$

This agreement, however, in the absence of a strong, central government vested with powers to administer it, had no more force or effect than any other treaty between states, and the return of the criminal fugitive, or escaped prisoner depended almost entirely upon the discretion of the government of the asylum state.

The Constitution later adopted, however, sought to change this status, and was not formed merely to guard the states against danger from foreign nations, but mainly to secure union and harmony at home, and safety against injustice from one another. ${ }^{13}$ Certain definite and enumerated powers were conferred upon the three coördinate departments of government, and these gave rise to implications of power not otherwise expressed. ${ }^{14}$

Among the powers thus enumerated and delegated was one dealing with the subject of interstate rendition. With some slight substantive changes, the provisions of the extradition compact of the Articles of Confederation were embodied in the Constitution. Article IV, Section 2, Clause 2, provides:

A Person charged in any State with Treason, Felony, or other Crime, who shall flee from Justice, and be found in another state, shall on Demand of the executive Authority of the State from which he fled, be delivered up, to be removed to the State having Jurisdiction of the Crime.

${ }^{9}$ Matter of Fetter, 3 Zab. 3 II, 57 Am. Dec. 382 (N. J. I852).

${ }^{10} 3$ Keble, 785, 84 Eng. Repr. rori (1677).

$\mu_{2}$ Vent. 314,86 Eng. Repr. 460 (1690).

10 ARt. or Confed. art. Iv, par. 2.

${ }^{13}$ See League v. De Young, xi How. 185, 203 (U. S. I85I); Ableman v. Booth, 2x How. 506, 517 (U. S. I859); 6 R. C. L. (I9I5) 21 .

II 6 R. C. L. (1915) 134 . 
It was intended by this provision of the Constitution to confer authority upon Congress to deal with such subject. The Act of $1793^{15}$ was enacted for the purpose of controlling the subject in so far as it was deemed wise to do so, and its provisions were intended to be dominant and, so far as they operated, controlling and exclusive of state power. ${ }^{16}$

This statute made it the duty of the governor of an asylum state, upon requisition of the executive of the state of primary jurisdiction over the fugitive and his crime, to honor the demand and issue his warrant authorizing arrest and removal. But in a case decided by the Supreme Court of the United States in $186 \mathrm{r},{ }^{17}$ where the governor of Ohio refused to honor the requisition of the executive of Kentucky, and mandamus was sought in the Supreme Court to compel him so to do, it was discovered that in spite of the duty imposed upon him by act of Congress, the federal court was powerless in the premises; and it was held that while extradition between the states is provided by the United States Constitution, ${ }^{18}$ and the Congress has enacted laws thereon, ${ }^{19}$ if the governor of the asylum state refuses to discharge his duty, there is no power delegated to the general government, either through the judicial department or any other department, to use any coercive means to compel him.

Thus it appeared that the central government was powerless in the premises, that the matter of rendition in any particular case rests entirely in the discretion of the governor of the asylum state, and that should he choose to consider extraneous evidence bearing upon the guilt or innocence of the accused, or other facts actually barred from his province, whether political or otherwise, he might do so with impunity. Just how many abuses have actually arisen because of this deplorable condition of affairs we do not profess to know. But the fact remains that up to the moment when the Congressional Act of May 18, r934, was approved by the President, the governors of asylum states held the key to the situation. It will be readily seen, therefore, that in respect to interstate rendition alone, without reference to its other provisions respecting witnesses, the measure is an extremely salutary one, well calculated and designed to render immeasurable assistance and aid to conscientious enforcers of the criminal law. No longer may the criminal offender hide behind the skirts of a politically-minded chief executive, but on proper complaint to the federal authorities of the district from whence the criminal has fled, steps may be taken for the speedy return of the offender. ${ }^{20}$

${ }^{15}$ I STAT. 302, 8I U. S. C. A. $\$ 662$.

${ }^{16}$ Innes v. Tobin, 240 U. S. 127,36 Sup. Ct. 290 (IgI6).

${ }^{27}$ Supra note 8.

${ }^{20}$ Procedure for the removal of a person accused of a federal crime from the federal judicial district in which he is found to that in which he is to be tried is more expeditious than that employed between states. The order of removal is issued by the federal district judge after a hearing usually held before a United States Commissioner. See I Stat. (I789) 9I, as amended, $18 \mathrm{U}_{\mathbf{2}}$ S. C. A. \$59r; Hardy, Removal of Federal OfFenders (1929) 9. The provision in the 1934 Act that the crime shall be deemed to have been committed in the district from which the fugitive fled assures that the place of trial will be within that district. The federal prisoner, when brought within the confines of the state, will, of course, be subject to state criminal process. 
While this is a "consummation devoutly to be wished," the provision of the Act which makes it possible to bring a fleeing witness within the territorial jurisdiction of the court of crminal jurisprudence, where the culprit may be dealt with expeditiously, is of still more vital importance to those charged with orderly administration of the laws. It has often happened, within the experience of the writers of this article, that men actually guilty of the crime of first degree murder have escaped just and merited punishment because they have succeeded in inducing the only witness of their crime to flee across the state line.

Prior to the passage of this Act of Congress, the Michigan state legislature, in adopting a code of criminal procedure, provided, in substance, for the rendition of witnesses to other states and countries. ${ }^{21}$ It authorizes the issuance of a witness subpoena by any court of competent jurisdiction, commanding the person to attend the court of the interested state or country and testify in the pending criminal proceeding. But this act may be invoked only by the authorities of those nations or states which have adopted a reciprocal measure according to Michigan like privileges and courtesies. ${ }^{22}$ Thus limited, it is seldom utilized and, moreover, possesses certain weaknesses in its administration. Manifestly, should a witness flee from Ohio to Michigan, and there be served with a subpoena to appear at a session of the court of common pleas, subject only to the penalty of contempt proceedings instituted before some Michigan judge, further escape might be had by crossing the international boundary line into Ontario or by travelling on to Chicago. There is no provision for his arrest and surrender.

Article II, Section I9, of the Michigan constitution contains a provision found in the "bill of rights" of the majority of states. It reads as follows:

Sec. I9. In every criminal prosecution, the accused shall have the right . . . to be confronted with the witnesses against him; to have compulsory process for obtaining witnesses in his favor; ...

Sections 77 and 78 , of Chapter 7 of the Michigan code of criminal procedure, in line with other state codes, contains the following provisions:

Sec. 77. When an issue of fact shall be joined upon any indictment, the court in which the same is pending may, on application of the defendant, grant a commission to examine any material witnesses residing out of this state, in the same manner as in civil cases.

Sec. 78. Interrogatories to be annexed to such commission shall be settled and such commission shall be issued, executed and returned in the manner prescribed by law in

${ }^{21}$ Mich. Pub. Acts r927, No. I75, c. 7, \$80, 3 Мich. Cosrp. LAws (Cahill, 1929) \$17283, as amended by Mich. Pub. Acts 1931, No. 309.

${ }^{2}$ In addition to Michigan, the following states have statutes providing for the securing of witnesses from other states in criminal prosecutions: Connccticut, Iowa, Maine, Massachusetts, Nevada, New Hampshirc, Ncw York, North Dakota, Rhode Island, South Dakota, Vermont, and Wisconsin. Of these only the Connecticut, New Hampshire, and Vermont acts are not reciprocal. The Uniform Act to Secure the Attendance of Witnesses from Without the State in Criminal Cases, which is reciprocal, has been adopted by six of the foregoing states. See 9 UN. Laws Ans. (Supp. 1934) 6. This Act is digested in Dean, The Interstate Compact-A Device for Crime Repression, infra at p. 469 . 
respect to commissions in civil cases, and the deposition taken and returned thereon shall be read in the same cases, and with like effect in all respects as in civil cases. ${ }^{23}$

Consideration of the constitutional provision, which recognizes the right to be confronted by the witnesses, in conjunction with the statutory mandate authorizing the taking of depositions of witnesses in foreign jurisdictions "on application of the defendant," further illustrates the unjust and unfair balance which is sometimes struck between the rights of the individual accused and the rights of the community wronged by his criminal acts. Protected by the constitutional provision recognizing the right of confrontation with the witnesses, the accused may rest assured that the testimony of state's witnesses cannot be taken outside the jurisdiction of the court without his express consent. And, under the privileges accorded him by the code, he is likewise confident of the right to produce the testimony of foreign witnesses "in his favor."

It has been held by the majority of courts, including Michigan, that depositions in criminal cases, which were unknown and unauthorized at common law, ${ }^{24}$ are barred from evidence in criminal cases, on behalf of the state, in all courts of record.

Quite early in its history, the Supreme Court of Michigan held, obiter dictum, that the Constitution does not permit the taking of depositions in criminal cases. ${ }^{25}$ And this principle has since been recognized, though the state may introduce in evidence the testimony of a witness taken on a former trial, when the witness has since died, or become incapacitated, provided the privilege of cross-examination was accorded the defendant in the first instance. ${ }^{26}$ And an accused person on trial, personally or through his counsel may waive the constitutional right to confrontation of witnesses. ${ }^{27}$

The basic principle underlying the rule of confrontation is that it serves the primary purpose of conserving the right of cross-examination. While this may be just, yet, with all due respect for the opinions of courts of last resort, might it not be said that the taking of a deposition in behalf of the state, in a foreign jurisdiction, upon proper auspices, and at the expense of the prosecution, where adequate opportunity would be afforded to indulge fully in cross-examination, under charge of a judicial officer, would do no violence to constitutional rights? It might be said that this view fails to consider the advantage derived by judge and jury from observation of the conduct and demeanor of the witness on the stand. Granting this to be true, does not the state suffer the same disadvantage when a witness, "on application of the defendant," testifies before a commissioner in a foreign state? And should a criminal be permitted to escape his just punishment simply because of such advan-

\footnotetext{
^3 3 Mick. Comp. Laws (Cahill, I929) $\$$ I7291, I7292. (Italics added.)

218 R. C. L. (1915) 86; ibid. Ir34. State v. Hill, 2 Hill 607,27 Am. Dec. 406 (S. C. 1835); Ex parte Harkins, 6 Ala. 63, 4 I Am. Dec. 38 (I844); Blanchard v. State, 2x Okla. Crim. Rep. 263, 207 Pac. 96

$\approx$ People v. Sligh, 48 Mich. 54 , Ix N. W. 782 (1882).

$\approx$ Pcople v. Droste, I60 Mich. 66, I25 N. W. 87 (I910).

" People v. Murray, 52 Mich. 288, I7 N. W. 843 (1883).
} (I922). 
tages and disadvantages? Has not the time arrived when we must strike a more even balance between the rights of the accused and the rights of the state?

To balance the equities between accuser and accused, to prevent felonious escape on somewhat technical grounds and, at the same time, restrain the flight of witnesses from the performance of their most sacred duty as citizens, and, in a measure, to insure their return, are the primary objects and purposes of this Congressional Act. If constitutional, it will give to the prosecuting official an effective weapon in his enforcement of the law.

We say, advisedly, "if constitutional," for this test is yet to be met.

If there be justification for the Act, it will be found in Article I, Section 8, Clause 3, of the Federal Constitution, which delegates to the Congress power, "to regulate Commerce with foreign Nations, and among the several States, and with the Indian Tribes."

Does the Act come within this field?

In our article published in the June number of the Detroit Law Review, ${ }^{28}$ we considered several of the cases decided by the Supreme Court of the United States, the majority of which have sustained acts of Congress designed to regulate and control interstate commerce. Had the words of the Constitution been given their narrow and technical meaning, then without doubt the Congress would have been limited to the regulation of goods and chattels transported in the course of trade from state to state. But the Supreme Court, early in its history, gave the provision a liberal construction, and permitted the Congress to go far afield. Under these decisions, the delegated powers contained in this article and section have been stretched to the limit, and, while it was not intended by the founders that the central government should exercise extensive police powers, nevertheless the Supreme Court has directly sanctioned certain acts of the Congress which have dealt more with morals than with trade. This is, we believe, as it should be. Not to deprive the individual state governments of any of their police powers, but to supplement such powers, to give them life, to aid and assist the states in the administration of their laws-such is the spirit of the decisions to which reference has been had.

We take the liberty, at this time, of citing in the footnotes certain of the more important cases decided by our Supreme Court in construing and implementing this provision of the Constitution, and in defining the limits beyond which the Congress may not go in regulating interstate and foreign commerce. ${ }^{20}$

supra note 2.

$\approx$ Jacobson v. Massachusetts, r97 U. S. 11, 25 Sup. Ct. 358 (1904), defining the police powcr of the states.

Lambert v. Yellowley, 272 U. S. 581, 47 Sup. Ct. 2ro (1926); Hamilton v. Kentucky Distillerics, ctc. Co. 25 I U. S. I46, 40 Sup. Ct. 106 (I919); Rupert v. Caffey, 25 I U. S. 264, 40 Sup. Ct. 14I (I919), holding that exercise of constitutional fecleral power may be attended by incidents of police power and may accomplish a similar purposc.

Gibbons v. Ogden, 9 Wheat. I (U. S. 1824). Justice Marshall's definition of "commerce."

New York v. Miln, II Pet. 102 (U. S. I837), expressly overruled in Smith v. Turner, 7 How. 282 (U. S. r 849), holding that passengers from one state to another are subjects of commerce within the exclusive jurisdiction of the Congress to regulate. 
Summing up such arguments as we advanced, in our former article, to sustain the validity of this act, we repeat what was said on that occasion:

Thus it will be seen, from a study of the cases cited, as well as other authorities to which attention might possibly be directed, that the broad plenary power of the Congress to regulate interstate commerce has by judicial construction been extended to cover many situations which, technically speaking, do not come within the field of commerce in its narrower sense. As defined by our highest court, "commerce" includes not only the transportation of articles of trade, but the passage from state to state of persons as well, and more especially and appropriately is this true where such passage or transportation is for the purpose of furthering immorality, dishonesty, crime, or any other endeavor inimical to the welfare of the nation, or any state of the union. In short, as we have already observed, the tendency grows stronger to exercise this plenary power as a means of controlling, regulating and prohibiting crime itself.

If the rule laid down by our supreme court may be applied to foot passengers over an interstate bridge, to women travelling for immoral purposes, to diseased cattle, to stolen motor vehicles, and, latterly, to kidnapers, why should it not be extended to cover those persons who defeat the due administration of justice by fleeing from state to state in order that they may escape performance of their duty to testify as witnesses in criminal prosecutions? Such conduct strikes at the very roots of government and defeats the purpose for which sociely is organized.

Although it may be impossible to predict the ultimate judicial fate of this legislative measure in the event of attack on constitutional grounds, so long as the question is open it is our opinion that the act does not interfere with the exercise of any governmental powers inherent in the states; that it constitutes a legitimate exercise of one of the enumerated powers expressly delegated to the Congress; and that, under such sanction, it affords to law-enforcing agencies throughout the country a necessary and much-needed weapon.

Pensacola Telegraphic Co. v. Western Union Telegraph Co., 96 U. S. I, (1877), extending the term "commerce" to include the sending of telegraphic messages from state to state.

Covington \& Cincinnati Bridge Co. v. Kentucky, $x_{54}$ U. S. 204, I4 Sup. Ct. 1087 (1894), holding that foot-passengers and other traffic over an interstate bridge are within the exclusive power of the Congress to regulate.

Champion v. Ames, 188 U. S. 321,23 Sup. Ct. 321 (1903), discussing the "bridge case," supra, and, under the principles there laid down, sustaining an act of the Congress which prohibited the carriage of lottery tickets.

Hoke v. United States, 227 U. S. 308, 33 Sup. Ct. 28x (1913) and Caminetti v. United States, 242 U. S. 470,37 Sup. Ct. 192 ( 1917 ), sustaining as constitutional the Mann Act, or "White Slave Law," so-called, forbidding the transportation, etc., of women for immoral purposes.

Hammer v. Dagenhart, 247 U. S. 251, 38 Sup. Ct. 529 (rgr 8), distinguishing the Hoke and Caminetti cases, supra, and holding unconstitutional the Child Labor Law, so-called. This, in our opinion, is the only authority which might possibly prove a stumbling block to the act in question.

United States v. Hill, 248 U. S. 420,39 Sup. Ct. I43 (I9I9), ruling that the Congress may exercise its plenary authority over interstate commerce either in aid of or without reference to the particular policy of law of any given state.

Brooks v. United States, 267 U. S. 432, 45 Sup. Ct. 345 (I925), upholding, as against constitutional objections, the Dyer Act, barring from interstate commerce a motor vehicle "knowing the same to have been stolen." There said by Chief Justice Taft: "The objection to the act cannot be sustained. Congress can certainly regulate interstate commerce to the extent of forbidding and punishing the use of such commerce as an agency to promote immorality, dishonesty, or the spread of any evil or harm to the people of other states from the state of origin. In doing this it is mercly exercising the police power, for the benefit of the public within the field of interstate commerce."

And see Thornton v. United States, 27 I U. S. 414,46 Sup. Ct. 585 (1926). 